\title{
Windows Wound Down
}

\section{PAM BROWN}

parked under

a chalky old light pole,

windows wound down,

dozing on the front seat,

on the radio

Chinese classical music

hot night tonight,

across the road

a man is wearing

his hat, indoors.

the stars that I love,

when I remember

to look at them,

blink above the building

I've memorised

a Keats sonnet

for February

a Tom Clark poem 
for March

\&

julienned the carrots

for spicy carrots

with harissa, cumin,

parsley, garlic, lemon,

while listening

to crazy music -

Albert Ayler

a Czech poetry paperback

bought in 1971,

there's a 30 cent ticket

to the Penguin Reserve

on Phillip Island

and a poignant note

tucked between the pages

of a poem marked with a pencilled ' $\mathrm{x}$ '

' $\mathrm{x}$ ' - Vladimir Holan, Changes -

This is our hope: that we have passed

the limits of the last reality.

But while consciousness disappears

it is the very consciousness

whose constant changes

remain ...

the note-

$\mathrm{P}$

I can't bring myself to write

what's in my head

I am splitting up north I guess

I love you 
The Collected Poems

of Gwen Harwood

is on the table

but I should

prepare a talk

for Zines in April

$*$

going on online,

a small discussion

(between 3 poets)

about experimental poetry

and free verse that one poet says

is really

anecdotal 'sincerity'

wrapped up in the unified ' $I$ '

oh dear I think that must mean me,

with whom I am definitely stuck,

I have

my limitations, though

not always 'sincere',

and never 'unified' -

only paranoid

$*$

do carpenters

read novels

about carpenters?

do pastrycooks

about pastrycooks?

poets read novels 
by poets,

like

Roberto Bolano

yes, it seems so

*

another phone call

more cancer

and another

a month later

like Michael said,

now we'll spend

the rest of our lives

watching our friends die.

$*$

End of the First Week

by the time they caught Karadzic

everyone here had forgotten

who he was, what he'd done

water on mars?

let's fuck mars up too

space terrain

flag a claim,

space fear sphere,

see you tomorrow

*

why not

recalibrate your lifestyle 
how did Jean Genet

live in hotels

for so long?

*

she wiped her face

with the wettex

then turned to kiss me

let me

track your parcel

darling

$*$

find a city,

well, find a city first, I agree,

find myself a city to live in.

David Byrne, Cities

I can't google-map my past,

where we lived is classified

cept

f u Peter P !

u know y

$*$

walk the spoodle

and the labradoodle

past the pot of pesto

under the patio gas heater

grown men

with ridiculous dogs 
End of the Second Week

*

the podiatrist's fingertips

are orange with nicotine,

my corn recoils

$*$

lithium eclipse

a new cocktail

ice wine

a minor fever

$*$

booking into

the Nasty Uncles Hotel

one moonlit night,

a double-bed room,

a nasty argument,

a bus stop

$*$

the first Koreans of the season,

cloth hats, one silver coolie,

comic-print backpacks,

peering over fences at plants

imported from Korea-

it's Spring

$*$

End of the Third Week

$*$

gone solar 
cicadas sucking sap

underground -

that's optimism

$*$

I'm not going

to Zines in April,

too old too tired too late

but

still in opposition -

dead prepositions,

and needless adverbs

industrialising pollination

my white paper poem

has

no conclusion

I would like to see

some viridian,

in my opinion

a neglected colour

End of the Month 